\title{
Correction: Progress towards millennium development goal 1 in northern rural Nicaragua: Findings from a health and demographic surveillance site
}

\author{
Wilton Pérez ${ }^{1 *}$, Elmer Zelaya Blandón², Lars-Åke Persson', Rodolfo Peña ${ }^{1,3}$ and Carina Källestål ${ }^{1}$
}

\section{Correction}

After publication of our article Pérez et al Int J Equity Health 2012 11:43, we became aware of some errors in the final published version, for which the corresponding author accepts full responsibility.

Page 3: third paragraph, Lines 2-4: “..., microcredit, and technical training for those ages 15 to 30 " should be read "..., microcredit for those ages 15 to 65 , and technical training for those ages 18 to 40 ".

The original Table four (Table 1) has some incorrect figures. We have corrected these figures in the updated table.

Because new corrected figures in the original Table four (Table 1) the following statement should be changed: Page 5: third paragraph, Line 7: “...provision of technical training in both years,..." should be read “...provision of technical training in 2004,...". Page 7: first paragraph, Lines 7-8: "Although the distribution of technical education was found to be unequal, there was a significant relationship between..." should be read "Although the distribution of technical education was found to be unequal in 2004, it was equal in 2009, and it showed a significant relationship between...". These corrections do not affect the rest of the data analysis.

We regret any inconvenience that this oversight may have caused.

Table 1 Distribution of microcredit, home gardens and technical training interventions rate per 1000 by level of poverty (non-poor, poor, and extremely poor), Cuatro Santos, Nicaragua, 2004 to 2009

\begin{tabular}{|c|c|c|c|c|}
\hline Program & & & & \\
\hline Microcredit & Population Ages 15-65 & & Population Ages 15-65 & \\
\hline Non-poor & 3,044 & $2.3(7)[1.0-4.9]^{1}$ & 6,229 & 27.9 (174) [24.0-32.4] \\
\hline Poor and extremely poor & 9,039 & $1.2(11)[0.6-2.2]$ & 8,439 & 14.8 (125) [12.3-17.6] \\
\hline Home gardens & Households & & Households & \\
\hline Non-poor & 1,095 & $6.4(7)[2.8-13.7]$ & 2,111 & $36.0(76)[28.6-45.0]$ \\
\hline Poor and extremely poor & 3,356 & $6.9(23)[4.4-10.4]$ & 2,926 & 40.0 (117) [33.3-47.8] \\
\hline Technical training & Population Ages 18-40 & & Population Ages $18-40$ & \\
\hline Non-poor & 1,831 & $12.6(23)[8.1-19.1]$ & 3,514 & 14.2 (50) [10.6-18.8] \\
\hline Poor and extremely poor & 5,228 & 2.7 (14) [1.5-4.6] & 4,980 & 13.8 (69) [10.8-17.5] \\
\hline
\end{tabular}

'Data are presented as rate (n) with $95 \% \mathrm{Cl}$. Italics indicate significant differences when $95 \% \mathrm{Cl}$ do not overlap.

\footnotetext{
* Correspondence: wilton.perez@kbh.uu.se

${ }^{1}$ International Maternal and Child Health (IMCH), Department of Women's

and Children's Health, Uppsala University, Uppsala 75185, Sweden

Full list of author information is available at the end of the article
} 


\section{Author details}

${ }^{1}$ International Maternal and Child Health (IMCH), Department of Women's and Children's Health, Uppsala University, Uppsala 75185, Sweden.

${ }^{2}$ Asociación para el Desarrollo Económico y Social de El Espino (APRODESE)

León, Nicaragua. ${ }^{3}$ The Centre for Research and Interventions in Health (CIS),

León, Nicaragua.

Received: 31 October 2012 Accepted: 31 October 2012

Published: 23 November 2012

\section{Reference}

1. Pérez W, Zelaya Blandón E, Persson LA, Peña R, Källestål C: Progress towards millennium development goal 1 in northern rural Nicaragua: Findings from a health and demographic surveillance site. Int J Equity Health 2012, 11:43.

doi:10.1186/1475-9276-11-72

Cite this article as: Pérez et al:: Correction: Progress towards millennium development goal 1 in northern rural Nicaragua: Findings from a health and demographic surveillance site. International Journal for Equity in Health 2012 11:72.

\section{Submit your next manuscript to BioMed Central and take full advantage of:}

- Convenient online submission

- Thorough peer review

- No space constraints or color figure charges

- Immediate publication on acceptance

- Inclusion in PubMed, CAS, Scopus and Google Scholar

- Research which is freely available for redistribution 